\title{
Using wireless rumen sensors for evaluating the effects of diet and ambient temperature in nonlactating dairy goats
}

\author{
A. Castro-Costa, ${ }^{*}$ A. A. K. Salama, ${ }^{*} \dagger$ X. Moll, $\neq$ J. Aguiló, $\S$ and G. Caja ${ }^{* 1}$ \\ *Group of Research in Ruminants (G2R), Department of Animal and Food Sciences, Universitat Autònoma de Barcelona, Bellaterra 08193, Spain \\ †Sheep and Goat Research Department, Animal Production Research Institute, 12311 Dokki, Giza, Egypt \\ † Group of Research in Experimental Surgery and Anesthesiology (GRESA), Department of Animal Medicine and Surgery, \\ Universitat Autònoma de Barcelona, Bellaterra 08193, Spain \\ §Group of Biomedical Applications (GAB), Department of Microelectronics and Electronic Systems, Universitat Autònoma de Barcelona, \\ Bellaterra 08193, Spain
}

\section{ABSTRACT}

Sixteen Murciano-Granadina dairy goats, provided with wireless rumen sensors for $\mathrm{pH}$ and temperature, were used to assess the rumen environment variations produced by extreme forage to concentrate diets (experiment 1) and climatic conditions (experiment 2). To avoid the interference of feed intake, goats were fed at maintenance level. Rumen sensors were inserted by surgery and programmed to collect and store rumen $\mathrm{pH}$ and temperature every $30 \mathrm{~min}$. In experiment 1, 8 dry goats $(38.6 \pm 2.3 \mathrm{~kg}$ of body weight) in tiestalls were divided into 2 groups and fed at maintenance level with 2 diets varying in forage-to-concentrate ratio [high forage (HF) 70:30; low forage (LF) 30:70] according to a crossover design. Diets were offered once daily for $4 \mathrm{~h}$ and tap water $\left(4 \mathrm{~L}, 9.8 \pm 0.4^{\circ} \mathrm{C}\right)$ was offered for only $30 \mathrm{~min}$ at $6 \mathrm{~h}$ after feeding. Rectal temperatures were recorded 3 times during the day. Rumen $\mathrm{pH}$ fell immediately after feeding, reaching a nadir depending on the diet $(\mathrm{HF}=6.35 \pm 0.07$ at $11 \mathrm{~h}$ after feeding; $\mathrm{LF}=6.07 \pm$ 0.07 at $6 \mathrm{~h}$ after feeding) and being on average greater $(0.31 \pm 0.06)$ in $\mathrm{HF}$ than LF goats. No diet effects were detected in rectal $\left(38.2 \pm 0.1^{\circ} \mathrm{C}\right)$ and ruminal $(38.9 \pm$ $0.1^{\circ} \mathrm{C}$ ) mean temperatures, which were positively correlated. Rumen temperature dramatically changed by feeding $\left(1.4 \pm 0.1^{\circ} \mathrm{C}\right)$ and drinking $\left(-3.4 \pm 0.1^{\circ} \mathrm{C}\right)$, and $2 \mathrm{~h}$ were necessary to return to the fasting value $(38.2$ $\left.\pm 0.1^{\circ} \mathrm{C}\right)$. In experiment 2,8 dry goats $(43.9 \pm 1.0 \mathrm{~kg}$ of body weight) were kept in metabolic cages, fed a 50:50 diet and exposed to 2 climatic conditions following a crossover design. Conditions were thermoneutral (TN; 20 to $23^{\circ} \mathrm{C}$ day-night) and heat stress (HS; 12 -h day at $37^{\circ} \mathrm{C}$ and 12 -h night at $\left.30^{\circ} \mathrm{C}\right)$. Humidity $(40 \pm 5 \%)$ and photoperiod (light-dark, 12-12 h) were similar. Goats were fed at maintenance level, the feed being offered

Received September 8, 2014.

Accepted March 31, 2015.

${ }^{1}$ Corresponding author: gerardo.caja@uab.es once daily and water at ambient temperature was freely available. Intake, rectal temperature, and respiratory rate were recorded 3 times daily. Despite no differing in dry matter intake, rumen $\mathrm{pH}$ was lower in HS than in TN goats $(-0.12 \pm 0.04)$. On the contrary, rumen temperature $\left(0.3 \pm 0.1^{\circ} \mathrm{C}\right)$, rectal temperature $(0.4 \pm$ $\left.0.1^{\circ} \mathrm{C}\right)$, respiratory rate $(77 \pm 5$ breaths $/ \mathrm{min})$, and water intake $(3.2 \pm 0.7 \mathrm{~L} / \mathrm{d})$ had a greater increase in HS than $\mathrm{TN}$, which might indicate an altered microbial fermentation under high temperature conditions. In conclusion, wireless bolus sensors proved to be a useful tool to monitor rumen $\mathrm{pH}$ and temperature as affected by different feeding and climatic conditions.

Key words: $\mathrm{pH}$, radiofrequency, rumen sensor, temperature

\section{INTRODUCTION}

Continuous data acquisition by telemetry allows dynamic measuring of responses and helps to define associations with management and environmental variables (Eigenberg et al., 2008; Rutten et al., 2013). Using wireless rumen boluses based on the use of radiofrequency, variation of rumen temperature by estrus and parturition (Cooper-Prado et al., 2011), viral diarrhea infection (Rose-Dye et al., 2011), SARA (AlZahal et al., 2009), and IMI (AlZahal et al., 2011) have been reported in cattle.

Changes in ambient temperature induce different responses in the nervous, circulatory, respiratory, renal, and endocrine systems, which allow the animal to cope with the altered environment. Different physiological, lactational, and nutritional responses to heat stress have been reported in ruminants: by Baumgard and Rhoads (2013) in dairy cows, and by Hamzaoui et al. (2013a) and Salama et al. (2014) in dairy goats. However, little is known about changes in rumen $\mathrm{pH}$ and temperature due to heat stress.

When feed intake was held constant in thermoneutral (TN) and heat stress (HS) environments, HS reduced 
the concentration of VFA in the rumen of cattle (Kelley et al., 1967), increased the concentration of lactic acid, and reduced ruminal $\mathrm{pH}$ (Mishra et al., 1970). Moreover, profiling the rumen microbiota by 16 s RNA gene cloning confirmed that HS induces significant changes in microbial diversity in heifers, resulting in a decrease of acetate and acetate-to-propionate ratio and an increase of butyrate, which substantially decreases the efficiency of absorption of VFA and the overall rumen pH (Tajima et al., 2007).

To our knowledge, telemetry has not been used to continuously measure changes in rumen environment in goats. Therefore, the objective of the present study was to evaluate the use of wireless sensors to assess the ruminal variations produced by diets with different forage-to-concentrate ratios and to monitor the effects of climatic conditions on the rumen environment of nonlactating dairy goats. To avoid confusion between reduced DMI and HS effects, both TN and HS goats were kept at the same level of feed intake to meet maintenance requirements.

\section{MATERIALS AND METHODS}

The experimental procedures and animal care conditions were reviewed and approved by the Ethical Committee on Animal and Human Experimentation of the Universitat Autònoma de Barcelona (reference CEEAH $11 / 1166)$ and the codes of recommendations for the welfare of livestock of the Ministry of Agriculture, Food and Environment of Spain.

\section{Wireless Rumen Sensors}

Wireless rumen boluses (model KB1001, Kahne, Auckland, New Zealand), designed for cattle heavier than $300 \mathrm{~kg}$ of $\mathrm{BW}$, were used for recording rumen $\mathrm{pH}$ and temperature in goats. Measurement ranges for temperature and $\mathrm{pH}$ were 0 to $45^{\circ} \mathrm{C}$ (accuracy $= \pm 0.08^{\circ} \mathrm{C}$ ) and 4.00 to 8.00 (accuracy $= \pm 0.02$ ), respectively. The whole telemetric Khane system included (1) rumen boluses $(27 \mathrm{~mm}$ diameter $\times 145 \mathrm{~mm}$ height, $70 \mathrm{~g}$ weight); (2) magnet blocker, to turn on and off the boluses; (3) top receiver, for capturing the data signals sent by the boluses (frequency $=433.9 \mathrm{MHz}$ ); (4) field receiver, with a directional antenna Yagi-Uda type (frequency $=400$ to $500 \mathrm{MHz}$ ); (5) trigger device, for transmitting the data to the storage device through radio frequency (Kahne wand); and (6) software (Kahne Data Processing System, v.5.2.4), for enabling the configuration and communication between the boluses and transceivers via a computer.

Boluses were calibrated before use according to the manufacturer instructions (Kahne, 2010) using deion- ized water at $40.0 \pm 0.5^{\circ} \mathrm{C}$ and $\mathrm{pH}$ buffer standard solutions of 4.01 and 7.00 (pH25, Crison Instruments, Barcelona, Spain). Measured and reference $\mathrm{pH}$ values correlated $\left(\mathrm{R}^{2}=0.99 ; P<0.001\right)$. Before the insertion of boluses into the rumen, previously stored data were erased and they were configured to record $\mathrm{pH}$ and temperature values every $30 \mathrm{~min}$.

In vivo validation was conducted using a rumen-cannulated dairy cow fed a maintenance diet (alfalfa hay ad libitum and $3 \mathrm{~kg} / \mathrm{d}$ of concentrate). Rumen content was sampled beside the bolus sensor at 10 time points $(0,2,6,10$, and $24 \mathrm{~h}$ during $2 \mathrm{~d})$, filtered through a cheesecloth for rumen liquor and $\mathrm{pH}$ measured using the previously indicated $\mathrm{pH}$ meter, to register extreme $\mathrm{pH}$ daily variations.

Boluses $(\mathrm{n}=8)$ were inserted into the rumen of goats through surgery (Dehghani and Ghadrdani, 1995). Goats were fasted for $24 \mathrm{~h}$ and were sedated by an i.m. injection of $0.3 \mathrm{~mL}$ of xylazine (Rompun $50 \mathrm{mg} / \mathrm{mL}$; Bayer Hispania, Barcelona, Spain) and 1 $\mathrm{mL}$ of ketamine (Ketamina $50 \mathrm{mg} / \mathrm{mL}$; Holliday-Scott, Buenos Aires, Argentina) before surgery. After washing, clipping, and disinfecting, a vertical incision of approximately $10 \mathrm{~cm}$ was made in the left flank, between the last rib and the iliac tuberosity. After pulling out the rumen wall to the incision with the help of towel clamps, a ruminotomy of $8 \mathrm{~cm}$ was done and the bolus was introduced into the rumen with its wings folded and tied to prevent damage to the rumen wall. After suturing the rumen wall, muscle layer, and skin, $2 \mathrm{~mL}$ of meloxicam anti-inflammatory (Metacam $20 \mathrm{mg} / \mathrm{mL}$; Boehringer-Ingelheim, Barcelona, Spain) and $4 \mathrm{~mL}$ of amoxicillin (Invemox $1.5 \mathrm{mg} / \mathrm{mL}$; Invesa, Barcelona, Spain) were i.m. injected for $5 \mathrm{~d}$. Goats were allowed to recover after surgery for $2 \mathrm{wk}$ in straw-bedded pens and fed alfalfa hay ad libitum.

A similar surgical procedure was followed to remove the boluses from the rumen at the end of the experiments. With this aim, the goats were lodged in strawbedded pens and fed alfalfa hay ad libitum for a resting period of 1 wk before surgery. Retrieved rumen sensors were washed with tap water and recalibrated as above indicated to calculate the drift error of the $\mathrm{pH}$ and temperature measurements.

\section{Experiment 1}

Animals, Management, and Treatments. Eight multiparous $(4.5 \pm 0.6 \mathrm{yr})$ nonlactating female Murciano-Granadina goats $(38.6 \pm 2.3 \mathrm{~kg}$ of $\mathrm{BW})$ from the herd of the Experimental Farm of the Servei de Granges i Camps Experiments of the Universitat Autònoma de Barcelona (Bellaterra, Barcelona, Spain) were used. Does were kept indoors in straw-bedded tiestalls at 
natural temperature and light conditions and individually fed and watered. The experiment was conducted during winter and minimum and maximum ambient temperatures in the barn averaged $10.0 \pm 0.4$ and 16.2 $\pm 0.5^{\circ} \mathrm{C}$, respectively, throughout the experiment.

The experimental design was a crossover with 2 treatments in 2 periods (lasting $19 \mathrm{~d}$ each) and 4 goats each. Does were switched to the opposite treatment in the second period with a 3 -d transitional period to gradually shift to the new diet. Dietary treatments consisted of high- and low-forage-to-concentrate ratio ( $\mathbf{H F}$ and LF, 70:30 and 30:70, respectively). Dehydrated fescue hay and whole barley grain (see composition in Table 1) were used to formulate the diets that cover the maintenance requirements of dry and open does according to INRA (2007). With the aim of identifying the rumen changes produced by feeding and drinking, diets were offered punctually once daily and for $4 \mathrm{~h}$ (distributed at $1130 \mathrm{~h}$ and withdrawn at $1530 \mathrm{~h}$ ), whereas tap water $\left(4 \mathrm{~L}, 9.8 \pm 0.4^{\circ} \mathrm{C}\right)$ was offered in individual buckets 2 $\mathrm{h}$ after feed removal $(1730 \mathrm{~h})$ for $30 \mathrm{~min}$. Does had free access to mineral-vitamin blocks in the stall (composition: $\mathrm{Na}=36.74 \% ; \mathrm{Ca}=0.32 \% ; \mathrm{Mg}=1.09 \% ; \mathrm{Zn}=5$ $\mathrm{g} / \mathrm{kg} ; \mathrm{Mn}=1.5 \mathrm{~g} / \mathrm{kg} ; \mathrm{S}=0.91 \mathrm{mg} / \mathrm{kg} ; \mathrm{Fe}=304 \mathrm{mg} /$ $\mathrm{kg} ; \mathrm{I}=75 \mathrm{mg} / \mathrm{kg} ; \mathrm{Co}=50 \mathrm{mg} / \mathrm{kg} ; \mathrm{Se}=25 \mathrm{mg} / \mathrm{kg} ;$ Ovi bloc, Sal Cupido, Terrasa, Spain).

Sampling, Measurements, and Analyses. Data were collected during the last $7 \mathrm{~d}$ of each experimental period. Samples of feed ingredients were taken at the start of the experiment and diets and orts were daily sampled, composited as representative samples, and stored at $4^{\circ} \mathrm{C}$ until analysis. Feed intake and water consumption were daily recorded. Samples were ground to pass through a 1-mm stainless steel screen (Cyclotec 1093 Sample mill, Tecator, Höganäs, Sweden) for chemical composition according to AOAC International (2003). The DM was determined at $103^{\circ} \mathrm{C}$ for $24 \mathrm{~h}$ and samples were burnt thereafter in a muffle furnace at $550^{\circ} \mathrm{C}$ for $4 \mathrm{~h}$ to measure their ash content. Crude protein $(\mathrm{N} \times 6.25)$ was analyzed according to the Dumas method for $\mathrm{N}$ determination using a Leco analyzer (Leco Corporation, St. Joseph, MI). The NDF and ADF were determined using an Ankom200 Fiber Analyzer incubator (Ankom Technology, Macedon, NY) adding $\alpha$-amylase and sodium bisulfite solutions. Chemical composition and nutritive value of the dietary ingredients are shown in Table 1.

Daily rectal temperatures were measured at 0900, 1300, and $1700 \mathrm{~h}$ using a digital clinical thermometer (Model mini color, ICO Technology, Barcelona, Spain; range $=32.0-43.9^{\circ} \mathrm{C}$; accuracy $= \pm 0.1^{\circ} \mathrm{C}$ ). Urine samples were manually collected from each goat when the animals woke up on the last day of each period and $\mathrm{pH}$
Table 1. Chemical composition and nutritive value (DM basis) of the rations

\begin{tabular}{|c|c|c|c|c|}
\hline \multirow[b]{2}{*}{ Item } & \multicolumn{2}{|c|}{ Experiment 1} & \multicolumn{2}{|c|}{ Experiment 2} \\
\hline & $\begin{array}{c}\text { Fescue } \\
\text { hay }\end{array}$ & Barley & $\begin{array}{c}\text { Alfalfa } \\
\text { hay }\end{array}$ & Barley \\
\hline \multicolumn{5}{|l|}{ Component, \% } \\
\hline $\mathrm{DM}$ & 91.7 & 91.0 & 88.6 & 89.5 \\
\hline $\mathrm{OM}$ & 88.3 & 97.1 & 87.4 & 97.4 \\
\hline $\mathrm{CP}$ & 10.7 & 9.6 & 20.0 & 10.8 \\
\hline $\mathrm{NDF}$ & 55.4 & 17.7 & 36.7 & 16.4 \\
\hline $\mathrm{ADF}$ & 32.5 & 5.9 & 27.0 & 6.1 \\
\hline $\mathrm{NFC}^{1}$ & 20.2 & 66.8 & 28.7 & 67.2 \\
\hline \multicolumn{5}{|l|}{ Nutritive value $^{2}$} \\
\hline $\mathrm{UFL} / \mathrm{kg}^{3}$ & 0.72 & 1.05 & 0.72 & 1.06 \\
\hline $\mathrm{NE}_{\mathrm{L}}, \mathrm{Mcal} / \mathrm{kg}$ & 1.22 & 1.79 & 1.22 & 1.80 \\
\hline PDIE, ${ }^{4} \mathrm{~g} / \mathrm{kg}$ & 77 & 95 & 101 & 98 \\
\hline $\mathrm{PDIN}^{5}{ }^{5} \mathrm{~g} / \mathrm{kg}$ & 67 & 66 & 128 & 74 \\
\hline $\mathrm{PDIA},{ }^{6} \mathrm{~g} / \mathrm{kg}$ & 28 & 28 & 56 & 32 \\
\hline $\mathrm{Ca}, \mathrm{g} / \mathrm{kg}$ & 4.5 & 0.8 & 16.7 & 0.8 \\
\hline $\mathrm{P}, \mathrm{g} / \mathrm{kg}$ & 3.0 & 4.0 & 2.3 & 4.0 \\
\hline
\end{tabular}

${ }^{1}$ Fermentable carbohydrates not recovered in NDF, referred to as nonfiber carbohydrates (OM - NDF - CP - fat).

${ }^{2}$ Calculated according to INRA (2007).

${ }^{3}$ Feed units for lactation $\left(1 \mathrm{UFL}=1.7 \mathrm{Mcal} \mathrm{NE} \mathrm{L}_{\mathrm{L}}\right)$.

${ }^{4}$ Protein digested in the small intestine supplied by microbial protein from rumen-fermented OM.

${ }^{5}$ Protein digested in the small intestine supplied by microbial protein from RDP.

${ }^{6}$ Protein digested in the small intestine supplied by RUP.

was measured using a portable $\mathrm{pH}-$ meter ( $\mathrm{pH} 25$, Crison Instruments) within $1 \mathrm{~h}$ after collection.

\section{Experiment 2}

Animals, Management Conditions, and Treatments. Eight Murciano-Granadina nonlactating does $(43.9 \pm 1.0 \mathrm{~kg}$ of BW; $4.3 \pm 0.8 \mathrm{yr})$ previously adapted (1 wk) to metabolic cages were used. The experimental design was a crossover with 2 treatments in 2 periods lasting $21 \mathrm{~d}$ each (adaptation $=14 \mathrm{~d}$; measuring and sampling $=7 \mathrm{~d}$ ) and 4 goats in each group. Does were switched to the opposite treatment in the second period of $21 \mathrm{~d}$.

Treatments consisted of different ambient conditions - (1) TN and (2) HS - according to their thermohygrometric index $[\mathbf{T H I}=1.8 \times \mathrm{T}+32-(0.55-$ $0.0055 \times \mathrm{RH}) \times(1.8 \times \mathrm{T}-26.8)$, where $\mathrm{T}$ is the air temperature and $\mathrm{RH}$ is the relative humidity (NRC, 1971); a value of THI $>75$ was considered as indicative of HS for dairy goats according to Silanikove (2000a) and Hamzaoui et al. (2013a)]. The TN does were kept in an air-conditioned room (Summit-Serie E10; Hitachi, Barcelona, Spain) maintained between 20 and $23^{\circ} \mathrm{C}$ with $45 \%$ relative humidity $(\mathrm{THI}=65-68)$. The HS does were kept in a climatic chamber $(4 \times 6 \times 2.3$ 
m; ETS Lindgren-Euroshield Oy, Eura, Finland) with temperature and humidity regulation (Carel Controls Iberica, Barcelona, Spain) set to $37^{\circ} \mathrm{C}$ (from 0900 to $2100 \mathrm{~h}$; $\mathrm{THI}=85$ ) and to $30^{\circ} \mathrm{C}$ (from 2100 to $0900 \mathrm{~h}$; THI $=77)$. Air turnover (ventilation $\left.=90 \mathrm{~m}^{3} / \mathrm{h}\right)$ and relative humidity $(\mathrm{RH}=40 \%)$ were maintained constant. A 12 and 12 h (light-dark) artificial photoperiod was maintained constant during the experiment in both cases (0900 to $2100 \mathrm{~h}$ ). When does were switched from TN to HS conditions, a transition period of $2 \mathrm{~d}$ was allowed ( 1 at $25^{\circ} \mathrm{C}$ and $\mathrm{d} 2$ at $30^{\circ} \mathrm{C}$ ) to avoid a thermal shock of the goats, but no transition was applied for the change from HS to TN because of the thermal stress alleviation.

Goats were fed a diet with 50:50 forage-to-concentrate ratio at maintenance level according to INRA (2007). The ration consisted of dehydrated alfalfa hay and barley (see composition in Table 1), the daily ration being individually calculated in accordance with the doe BW and INRA (2007) requirements. Feed was offered once a day at $1200 \mathrm{~h}$ and left for $24 \mathrm{~h}$. Mineralized salt blocks similar to experiment 1 were freely available in each metabolic cage (Ovi bloc, Sal Cupido). Clean water was freely available at ambient temperature for each treatment.

Measurements, Sampling, and Analyses. Rectal temperatures and respiration rates were daily recorded at 0900,1300 , and $1700 \mathrm{~h}$. The rectal temperature was measured with the same digital clinical thermometer used in experiment 1 . The respiration rate was measured by counting the inhalations and exhalations for $60 \mathrm{~s}$ with the aid of a chronometer.

Feed samples were collected before the beginning of each experimental period and analyzed as in experiment 1. Moreover, orts were daily collected, weighed, and composited for analysis as in experiment 1. All samples were ground through a 1-mm stainless steel screen, and analyzed for DM, CP, ADF, and NDF by adding $\alpha$-amylase and sodium bisulfite (AOAC International, 2003).

Digestibility measurements were done during the last 7-d of each experimental period. Feces were daily collected and $10 \%$ of fresh feces were dried at $60^{\circ} \mathrm{C}$ for $48 \mathrm{~h}$; then a composited sample for each goat was stored at room temperature and processed for analysis as previously indicated. Apparent digestibility (d) of each nutrient was estimated by the expression

$$
\mathrm{d}=(1-\text { excreted/ingested }) \times 100 .
$$

Water was freely available at room temperature (individual water tanks in each metabolic cage) and consumption was recorded daily by weight (accuracy
$= \pm 20 \mathrm{~g})$ during the digestibility period experiment. Trays with sawdust were put on the floor below the drinking troughs and weighed twice daily to take into account water leaks. Samples of urine were collected at micturition at 0800 and at $1700 \mathrm{~h}$ on the last 2 experimental days to measure urine $\mathrm{pH}$.

With the aim of checking the physiological stage of the goats at the end of the experiment, blood samples (approximately $0.3 \mathrm{~mL}$ ) were collected before feeding at $\mathrm{d} 21$ of the second period by using insulin syringes (1 mL BD Micro-Fine, BD Medical-Diabetes Care, Franklin Lakes, NJ). A single drop of blood was applied to disposable i-STAT EC8+ cartridges (Abaxis, Union City, CA) for analysis of glucose, urea, $\mathrm{Cl}, \mathrm{Na}, \mathrm{K}$, total $\mathrm{CO}_{2}$ concentration, anion gap, hematocrit, hemoglobin, $\mathrm{pH}$, partial pressure of $\mathrm{CO}_{2}, \mathrm{HCO}_{3}^{-}$, and base excess in blood using a VetScan i-STAT 1 hand-held analyzer (Abaxis) programmed for veterinary analysis of small ruminants.

\section{Statistical Analyses}

Data were analyzed by the PROC MIXED for repeated measurements of SAS version 9.1.3 including the repeated statement (SAS Institute Inc., Cary, NC). The statistical mixed model used for both experiments contained the fixed effects of the treatment (experiment $1=\mathrm{HF}$ vs. LF; experiment $2=\mathrm{TN}$ vs. HS), period (1 or 2$)$, sampling time (1 to 48 ), sequence of treatment ( 1 or 2$)$, interaction of treatment $\times$ sampling time, random effects of the animal (experiment $1=1$ to 8 ; experiment $2=9$ to 16 ), and residual error. Data of ruminal $\mathrm{pH}$ and temperature were averaged for the 7-d measurement period.

Data of digestibility and blood and urine measures taken in experiment 2 were analyzed by ANOVA using PROC GLM of SAS. The model contained the effects of treatment (TN or HS), period (1 or 2), the sequence of treatment ( 1 or 2 ), and the residual error.

Daily rumen $\mathrm{pH}$ and temperature data were used to calculate the sigmoidal curves representing the time below $(y-$ variate $=\mathrm{min} / \mathrm{d}$; ranging from 0 to $1440 \mathrm{~min} / \mathrm{d})$ each $\mathrm{pH}$ or temperature cutoff point ( $\mathrm{x}$-variate $=\mathrm{pH}$ or temperature values; ranging from 5.5 to 7.0 or from 35 to $41^{\circ} \mathrm{C}$, respectively) by the logistic regression $\{\mathrm{y}=\mathrm{a} /$ $\left[1+\mathrm{e}^{-(\mathrm{b}+\mathrm{cx})}\right]$; with a being the maximum value and $\mathrm{b}$ and $\mathrm{c}$ being the regression coefficients\} using the Solver Tool in Microsoft Excel (Harris, 1998), as indicated by AlZahal et al. (2007). This mathematical approach allowed the comparison of the inflection points, slopes and area under the curves (AUC) by integrating between 2 points $\left(\mathrm{pH}=5.5\right.$ to 7.0 ; temperature $=35$ to $\left.41^{\circ} \mathrm{C}\right)$, making objective the interpretation of the rumen $\mathrm{pH}$ and temperature complexities throughout the day. 
Table 2. Feed and water intakes, rectal and rumen temperatures, rumen and urine $\mathrm{pH}$ in nonlactating dairy goats of experiment 1 fed diets containing $70(\mathrm{HF} ; \mathrm{n}=8)$ or $30 \%$ forage $(\mathrm{LF} ; \mathrm{n}=8)$; values are LSM

\begin{tabular}{|c|c|c|c|c|c|c|}
\hline \multirow[b]{2}{*}{ Item } & \multicolumn{2}{|c|}{ Diet } & \multirow[b]{2}{*}{$\mathrm{SED}^{1}$} & \multicolumn{3}{|c|}{ Effect ( $P$-value) } \\
\hline & $\mathrm{HF}$ & $\mathrm{LF}$ & & Treatment & Period & Sequence $^{2}$ \\
\hline \multicolumn{7}{|l|}{ Daily intake } \\
\hline DM, g & 866 & 769 & 77 & 0.323 & 0.783 & 0.378 \\
\hline $\mathrm{CP}, \mathrm{g}$ & 104 & 90 & 9 & 0.170 & 0.897 & 0.385 \\
\hline $\mathrm{NDF}, \mathrm{g}$ & 446 & 263 & 38 & 0.005 & 0.983 & 0.456 \\
\hline $\mathrm{ADF}, \mathrm{g}$ & 246 & 126 & 21 & 0.003 & 0.952 & 0.488 \\
\hline $\mathrm{NFC}^{3} \mathrm{~g}$ & 296 & 406 & 42 & 0.045 & 0.856 & 0.567 \\
\hline $\mathrm{NE}_{\mathrm{L}}, \mathrm{Mcal}$ & 1.21 & 1.27 & - & - & - & - \\
\hline Water, L & 3.54 & 3.75 & 0.96 & 0.728 & 0.228 & 0.878 \\
\hline Rectal temperature, ${ }^{\circ} \mathrm{C}$ & 38.22 & 38.16 & 0.13 & 0.660 & 0.161 & 0.464 \\
\hline \multicolumn{7}{|l|}{ Rumen temperature, $\mathrm{RT}$} \\
\hline Average RT, ${ }^{\circ} \mathrm{C}$ & 38.82 & 38.92 & 0.12 & 0.396 & 0.156 & 0.783 \\
\hline $\mathrm{RT} \geq 38.8, \mathrm{~min} / \mathrm{d}$ & 908 & 938 & 126 & 0.851 & 0.659 & 0.606 \\
\hline $\mathrm{RT}>39.2, \mathrm{~min} / \mathrm{d}$ & 548 & 540 & 150 & 0.968 & 0.680 & 0.266 \\
\hline $\mathrm{RT} \geq 39.6, \mathrm{~min} / \mathrm{d}$ & 305 & 120 & 162 & 0.458 & 0.607 & 0.980 \\
\hline Rumen $\mathrm{pH}$ & 6.56 & 6.25 & 0.06 & 0.001 & 0.048 & 0.001 \\
\hline Urine $\mathrm{pH}$ & 7.65 & 7.67 & 0.20 & 0.923 & 0.063 & 0.540 \\
\hline
\end{tabular}

Differences between least squares means were determined with the PDIFF option of SAS. Pearson correlations were used to determine the relationship between the studied variables. Significance was declared as $P<$ 0.05 , unless otherwise indicated.

\section{RESULTS AND DISCUSSION}

Bolus sensors were found in the ventral sac of the goats at the surgery done at the end of each experiment. The overall $\mathrm{pH}$ sensor drift observed in both experiments was small and averaged $0.01 \pm 0.02$ and $-0.02 \pm 0.02$, for $\mathrm{pH} 4.01$ and 7.00 , respectively. These results indicate the stability of the sensor measurements throughout the experiments, agreeing with the previous findings of Mullins et al. (2012) and Hassanat et al. (2013) using the same type of bolus sensors in cows.

\section{Experiment 1}

Feed Intake and Water Consumption. According to the imposed feeding conditions, no differences $(P$ $=0.323$ ) were detected in DMI or water consumption of the HF and LF goats (Table 2). Moreover, water intake was predicted from DMI by using the GigerReverdin et al. (2011) equation for lactating dairy goats under temperate conditions. The measured value of water intake in our goats $(3.64 \pm 0.96 \mathrm{~L} / \mathrm{d}$, on average; Table 2) was $6 \%$ greater than the value estimated from the Giger-Reverdin et al. (2011) equation (3.44 $\mathrm{L} / \mathrm{d})$. On average, our dry and open does drank 4.5
$\mathrm{L} / \mathrm{kg}$ of DM of cold water, being able to consume the necessary amount of water under the restricted watering frequency conditions imposed in experiment 1 (i.e., once daily for $30 \mathrm{~min}$ ). This ability of dairy goats to adapt to single watering is based on the use of the rumen as a water reservoir, as previously described by Silanikove (2000b).

Ruminal $\boldsymbol{p H}$ and Temperatures. Mean daily rumen $\mathrm{pH}$ of HF goats was 0.31 units greater $(P<0.001)$ than that of LF goats (Table 2), according to their respective content in nonfiber carbohydrates as shown in Table 2. A similar effect on rumen $\mathrm{pH}$ was reported by Cantalapiedra-Hijar et al. (2009) in dry Granadina goats fed 70:30 or 30:70 forage-to-concentrate ratio diets (average $\mathrm{pH} 6.43$ and 6.26, respectively); the diet with the highest proportion of concentrate produced more VFA and had a greater concentration of lactic acid in the rumen according to Cantalapiedra-Hijar et al. (2009).

Although we did not compare the rumen pH measured by the bolus sensors or by direct $\mathrm{pH}$ meters in the goats, the in vivo validation (done in our study using a rumen-cannulated dairy cow) showed agreement, albeit with medium correlation coefficients between both measures (rumen $\mathrm{pH}, \mathrm{r}=0.63$; rumen temperature, $\mathrm{r}$ $=0.88 ; P<0.001)$. Lower correlations were observed in cows ( $\mathrm{r}=0.59$; Lohölter et al., 2013) and sheep $(\mathrm{r}=$ 0.46 ; Kaur et al., 2010) fed diets with different forageto-concentrate ratios, which may be a consequence of the differences between sampling points and type of sensors used. 


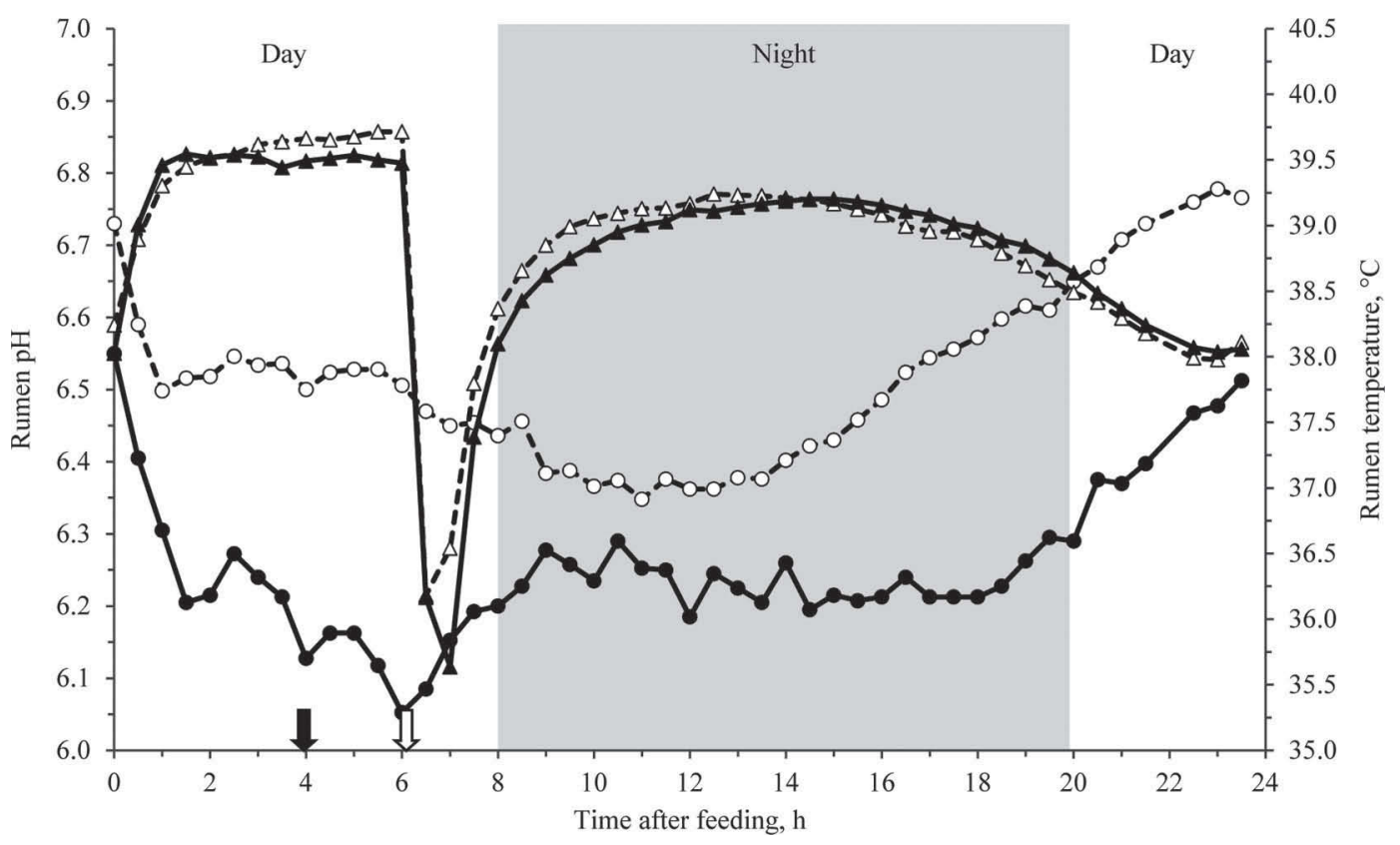

Figure 1. Rumen $\mathrm{pH}(\bigcirc$ and $\bullet)$ and rumen temperature $(\Delta$ and $\boldsymbol{\Delta})$ of nonlactating goats of experiment 1 fed diets with $70: 30(\bigcirc, \Delta ; \mathrm{n}=$ 8) or 30:70 $(\boldsymbol{\bullet}, \mathbf{\Delta} ; \mathrm{n}=8)$ forage-to-concentrate ratio at maintenance level. The solid arrow indicates the time of feed withdrawal and the open arrow indicates watering. The shaded area indicates natural night time (2000 to $0800 \mathrm{~h})$. The SEM values were 0.03 and 0.13 for rumen $\mathrm{pH}$ and temperature, respectively.

We are not aware of previous studies detailing rumen $\mathrm{pH}$ changes in goats over $24 \mathrm{~h}$ with short time intervals (i.e., every $30 \mathrm{~min}$ ) as done in our does, but GigerReverdin et al. (2014) recently compared the effects of extreme forage-to-concentrate diets (70:30 and 40:60) in rumen-cannulated dairy goats at 2-h intervals during the first $8 \mathrm{~h}$ after feeding. On average, values of rumen $\mathrm{pH}$ and acetate-to-propionate ratio for the 70:30 versus 40:60 diets were 6.28 versus 5.96 and 3.62 versus 3.09 , respectively, with rumen $\mathrm{pH}$ being permanently lower for the 40:60 diet according to Giger-Reverdin et al. (2014). In our data, the values of the rumen $\mathrm{pH}$ differed according to diet (Figure 1), the $\mathrm{pH}$ of LF goats being lower than of $\mathrm{HF}$ goats for all time points $(P<0.01)$ except during the middle of the night from 9 to $14 \mathrm{~h}$ postfeeding $(P=0.124)$. Moreover, both goat groups did not differ on the initial and final rumen $\mathrm{pH}$ values $(P=0.325)$. For the HF goats, a decrease of 0.37 units in rumen $\mathrm{pH}$ was seen, with a descending phase until $12.5 \mathrm{~h}$ postfeeding at which the nadir $(\mathrm{pH} 6.35 \pm 0.07)$ was observed. A further linear ascending phase until h 24 was observed $(P<0.001)$, as shown in Figure 1. Conversely, $\mathrm{pH}$ rapidly decreased in LF goats by 0.50 units during the first $6 \mathrm{~h}$ postfeeding, at which the nadir $(\mathrm{pH} 6.07 \pm 0.07)$ was observed, increased from 6.5 to $9 \mathrm{~h}(P<0.001)$, steadied from 9.5 to $18 \mathrm{~h}$, and finally increased rapidly from 18 to $24 \mathrm{~h}(P<0.001)$ to reach the initial value.
This change of curve pattern differs from that reported by Giger-Reverdin et al. (2014), who observed a lower rumen $\mathrm{pH}$ before and at all time points after feeding in the goats fed the 40:60 diet, the rumen $\mathrm{pH}$ nadir occurring at 2 to $4 \mathrm{~h}$ after feeding and the goats showing signs of milk fat depression and evidence of SARA (i.e., lower blood $\mathrm{pH}$, reduced intake, inverted fat-to-protein ratio in milk) when the rumen $\mathrm{pH}$ was under 6.0. This rumen $\mathrm{pH}$ threshold of 6.0 was not surpassed in our does.

Enemark et al. (2003) and Lohölter et al. (2013) reported a fall in rumen $\mathrm{pH}$ after feeding in dairy cows fed high-forage or high-concentrate diets, the nadir occurring at 2 to $3 \mathrm{~h}$ postfeeding regardless of the diet. Moreover, Lohölter et al. (2013) reported that highroughage diets induce a delayed microbial fermentation when compared with high-concentrate diets, which agrees with the slower reduction and later rumen $\mathrm{pH}$ nadir that was observed in our HF does, when compared with LF (Figure 1).

The increases in rumen $\mathrm{pH}$ at 12 (HF goats) and 18 $\mathrm{h}$ (LF goats) postfeeding observed in our results may be a result of the buffering effect of the saliva entering the rumen during rumination (Guilloteau et al., 1995). At both times, the goats were without feed (i.e., removed $4 \mathrm{~h}$ postfeeding) and resting in the middle of the night. The greater fiber content and particle size in the HF diet, when compared with the LF diet, may have pro- 
duced a longer rumination time and a greater buffering effect of the saliva in the rumen of the HF goats.

Rumen $\mathrm{pH}$ was modeled according to AlZahal et al. (2007) by accounting for the amount of time spent below pH cut-off points for both diets (Figure 2a). The values of the inflection points $(\mathrm{y}=720 \mathrm{~min} / \mathrm{d})$ on the sigmoidal curves for the HF $(\mathrm{pH}=6.50)$ and $\mathrm{LF}(\mathrm{pH}$ $=6.25)$ diets, representative of the ruminal acid-base neutralization reaction kinetics, were close to the average $\mathrm{pH}$ values reported in Table 2. Moreover, the AUC between $\mathrm{pH} 5.5$ and 7.0 were $718 \pm 145$ and $1,083 \pm$ $224 \mathrm{~min} / \mathrm{d}$ for HF and LF, respectively $(P=0.038)$. Despite the difference in forage-to-concentrate ratio between diets, the slopes of the sigmoidal curves were similar between $\mathrm{HF}$ and $\mathrm{LF}$ diets $(P>0.05)$, indicating a similar buffering capacity of the rumen of both groups of goats.

Rumen temperature values averaged $38.9 \pm 0.1^{\circ} \mathrm{C}$ and no differences were detected by diet throughout the experiment $(P=0.396$; Table 2$)$, which may be a consequence of feeding at maintenance level. AlZahal et al. (2009, 2011), Wahrmund et al. (2012), and Lohölter et al. (2013) reported greater rumen temperature with high-concentrate (40 to 65\%) diets in cattle fed ad libitum. Heat is a by-product of microbial fermentation (Hungate, 1966) and, therefore, diets containing a greater proportion of concentrate (i.e., greater fermentable OM) should generate a faster and greater peak of heat within the rumen when compared with high-forage diets (Arieli et al., 1988; Lohölter et al., 2013). Rumen temperature increased $(P<0.001)$ by 0.82 and $1.25^{\circ} \mathrm{C}$ at 30 and 60 min postfeeding, respectively, due to the increase in rumen fermentation activity in both goat groups, and remained elevated until drinking. Conversely, rumen temperature decreased by 3.42 and $3.51^{\circ} \mathrm{C}(P<0.001)$ at 30 and 60 min after drinking in $\mathrm{HF}$ and LF does, respectively (Figure 1). Afterward, values of rumen temperature recovered and gradually increased, but never reached the predrinking values because most feed was already consumed. During the last $3.5 \mathrm{~h}$ before the following meal, rumen temperatures slowly decreased and were similar $(P=0.135$ to 0.812$)$ to those before feeding (Figure 1).

Values of rumen temperature were also modeled using the logistic regression for both diets (Figure 2b). Despite the forage-to-concentrate ratio values used in the HF and LF diets, the inflection points $(\mathrm{y}=720$ $\mathrm{min} / \mathrm{d}$ ), representative of heat production kinetics in the rumen, mean temperature values $(38.96 \pm 0.15$ and $\left.38.95 \pm 0.12^{\circ} \mathrm{C} ; P=0.876\right)$, and AUC between 35 and $41^{\circ} \mathrm{C}\left(2,963 \pm 345\right.$ and $2,962 \pm 478 \mathrm{~min} / \mathrm{d}$ and ${ }^{\circ} \mathrm{C} ; P$ $=0.987)$ were similar and close to the average temperatures reported in Table 2 for the HF and LF diets, respectively.
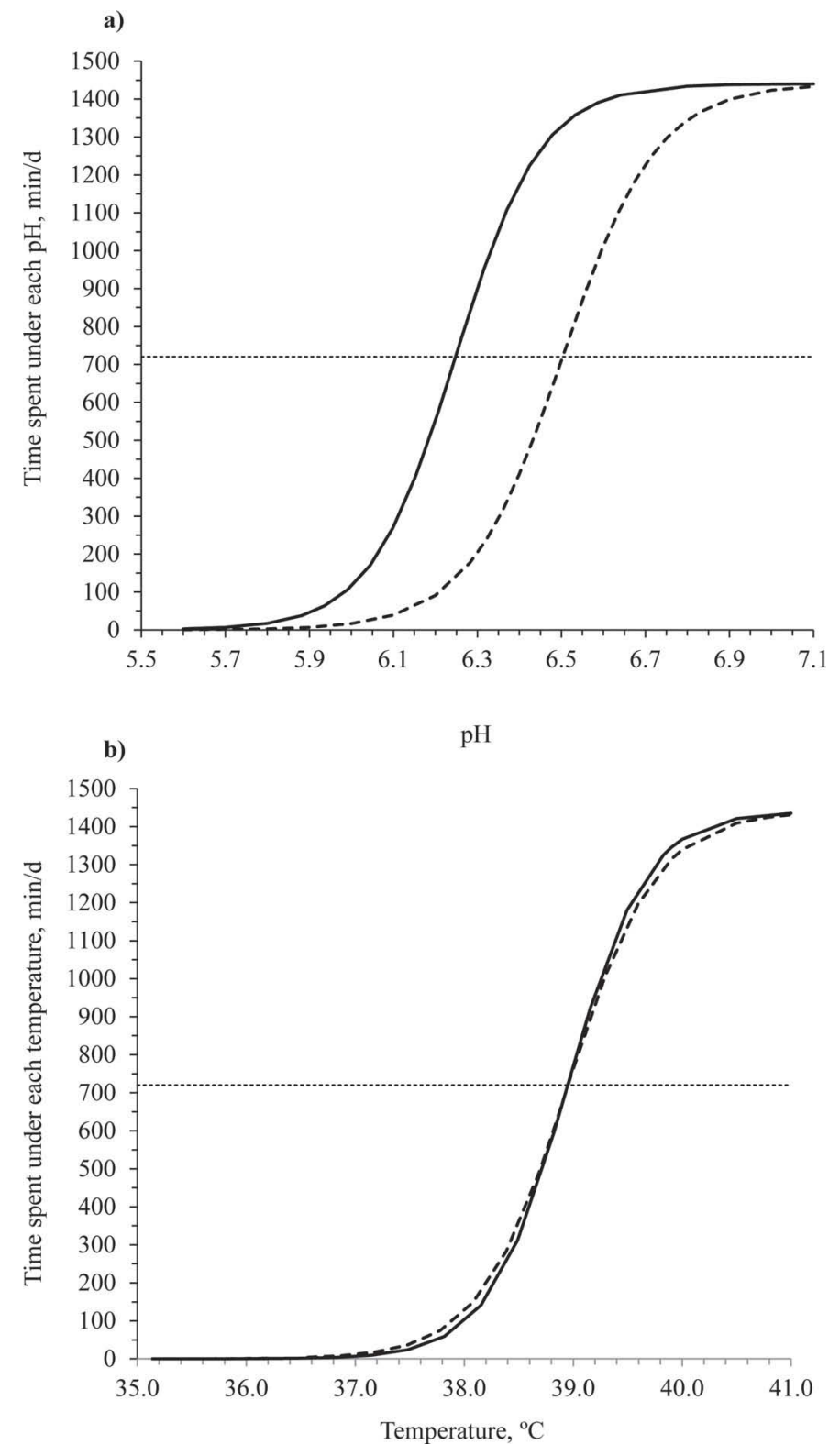

Figure 2. Logistic regression models for (a) the average rumen $\mathrm{pH}$ of goats of experiment 1 fed diets with 70:30 $\left(---; y=\frac{1440}{1+e^{57.896-8.903 x}}\right.$; $\left.\mathrm{R}^{2}=0.986\right)$ or $30: 70\left(-; y=\frac{1440}{1+e^{61.652-9.867 x}} ; \mathrm{R}^{2}=0.976\right)$ forage-toconcentrate ratio at maintenance level; and (b) the average rumen temperature of goats fed diets with 70:30 $\left(---; y=\frac{1440}{1+e^{96.466-2.477 x}}\right.$; $\left.\mathrm{R}^{2}=0.989\right)$ or $30: 70\left(-; y=\frac{1440}{1+e^{108.537-2.787 x}} ; \mathrm{R}^{2}=0.991\right)$ forageto-concentrate ratio at maintenance level. All regressions were $P<$ 0.001 . The $y$-axis represents the accumulated time $(\mathrm{min} / \mathrm{d})$ spent below each corresponding $\mathrm{pH}$ or temperature $\left({ }^{\circ} \mathrm{C}\right)$ point on the $x$-axis.

Does in the current experiment drank on average 3.9 $\pm 0.7 \mathrm{~L}(10 \%$ of $\mathrm{BW})$ of cold water $\left(9.8 \pm 0.4^{\circ} \mathrm{C}\right)$ within 5 to $10 \mathrm{~min}$. The decrease in rumen temperature after 
drinking in the current study $\left(-3.4^{\circ} \mathrm{C}\right.$ at $\left.30 \mathrm{~min}\right)$ was much lower than that reported by Bewley at al. (2008) in dairy cows $\left(-8.5^{\circ} \mathrm{C}\right.$ at $\left.15 \mathrm{~min}\right)$ drenched with $25 \mathrm{~L}$ (4\% BW approximately) of cold water $\left(7.6^{\circ} \mathrm{C}\right)$. In the later study, rumen temperature recovered at $3.5 \mathrm{~h}$ after water drenching, but in our results the values returned to normal range within $2 \mathrm{~h}$. It should be taken into account that boluses in the study of Bewley et al. (2008) were located in the reticulum, whereas in our goats boluses were in the ventral sac, which might explain differences in the magnitude of temperature reduction after drinking. We detected a positive correlation $(\mathrm{r}=$ $0.59 ; P<0.05)$ between the amount of water consumed $(2.6$ to $5.8 \mathrm{~L})$ and the decrease in rumen temperature $\left(-2.4\right.$ to $\left.-5.6^{\circ} \mathrm{C}\right) 30 \mathrm{~min}$ after water consumption. Drinking cold water may have produced a decrease in the body temperature of the goats, as reported by Bewley et al. (2008) in cows, and could be recommended as a strategy for alleviating HS during the hot hours of the day in lactating ruminants.

Because rumen temperature increased and rumen $\mathrm{pH}$ decreased after feeding, a negative low correlation was observed $(\mathrm{r}=-0.33 ; P<0.05)$ between both variables in our study, which agrees with the reports of Wahrmund et al. (2012; r $=-0.64$ to 0.09 ) and Lohölter et al. (2013; $\mathrm{r}=-0.11)$ using rumen sensors in steers and cows, respectively. This inverse relationship can be used to predict the rumen $\mathrm{pH}$ when related to critical points, as indicated by AlZahal et al. (2008), who reported $\mathrm{R}^{2}=0.77$ between minimum rumen $\mathrm{pH}$ and its corresponding rumen temperature in cows. Correlation between minimum rumen $\mathrm{pH}$ and corresponding rumen temperature was $\mathrm{R}^{2}=0.64(P<0.001)$ in our data.

Rectal Temperature and Relationship with Ruminal Temperature. No effect of the diet on rectal temperatures were detected (Table 2), agreeing with the findings of AlZahal et al. (2011) in cows. Conversely, rectal temperatures increased throughout the day $\left(0900 \mathrm{~h}=37.5 \pm 0.2^{\circ} \mathrm{C} ; 1300 \mathrm{~h}=38.4 \pm 0.2^{\circ} \mathrm{C}\right.$; $\left.1700 \mathrm{~h}=38.8 \pm 0.2^{\circ} \mathrm{C} ; P=0.008\right)$ by an effect of the rumen fermentation heat and the increase of ambient temperatures (from 10 to $16^{\circ} \mathrm{C}$ ).

Rumen temperatures were, on average, $0.68 \pm 0.06^{\circ} \mathrm{C}$ greater than rectal temperatures, agreeing with AlZahal et al. (2011), and increased throughout the day $\left(0900 \mathrm{~h}=38.2 \pm 0.2^{\circ} \mathrm{C} ; 1300 \mathrm{~h}=39.5 \pm 0.2^{\circ} \mathrm{C} ; 1700\right.$ $\left.\mathrm{h}=39.6 \pm 0.2^{\circ} \mathrm{C} ; P<0.001\right)$. A high and positive correlation was detected between both rectal and rumen temperatures $(\mathrm{r}=0.91 ; P<0.001)$.

\section{Experiment 2}

Feed Intake. Decrease of DMI due to HS usually ranges between 20 and $35 \%$ in lactating dairy goats fed ad libitum and according to stage of lactation (Hamzaoui et al., 2012, 2013a). In our data, HS goats reduced their intake by $13 \%$, although the difference between TN and HS treatments was not significant (Table 3; $P$ $=0.18$ ). It should be stressed that they were nonlactating and fed at maintenance level and, despite not differing in DMI, the TN goats gained and the HS goats lost BW during the experiment (Table 3), indicating a negative energy balance in the HS goats. Greater energy maintenance requirements during HS are expected to cover the needs for extra activities related to physical activity (i.e., panting), greater sweating, increased chemical reactions in the body, and the production of HS proteins that consume large amounts of ATP (McDowell et al., 1969; Beede and Collier, 1986; Salama et al., 2014).

Ruminal $p H$ and Temperature. On average, rumen $\mathrm{pH}$ of TN and HS goats decreased by $0.51 \pm 0.05$

Table 3. Body weight, DM and water intakes, respiration rate, rectal and rumen temperatures, and rumen $\mathrm{pH}$ of nonlactating goats of experiment 2 under thermal neutral $(\mathrm{TN}, \mathrm{n}=8)$ or heat stress $(\mathrm{HS}, \mathrm{n}=8)$ conditions; values are LSM

\begin{tabular}{|c|c|c|c|c|c|c|}
\hline \multirow[b]{2}{*}{ Item } & \multicolumn{2}{|c|}{ Treatment } & \multirow[b]{2}{*}{$\mathrm{SED}^{1}$} & \multicolumn{3}{|c|}{ Effect ( $P$-value $)$} \\
\hline & $\mathrm{TN}$ & HS & & Treatment & Period & Sequence $^{2}$ \\
\hline Initial BW, $\mathrm{kg}$ & 43.1 & 44.7 & 1.6 & 0.267 & 0.241 & 0.120 \\
\hline Final BW, kg & 44.4 & 43.3 & 1.4 & 0.469 & 0.287 & 0.080 \\
\hline BW change, $\mathrm{kg}$ & 1.3 & -1.4 & 1.1 & 0.033 & 0.013 & 0.633 \\
\hline DMI, $\mathrm{kg} / \mathrm{d}$ & 1.13 & 0.98 & 0.10 & 0.183 & 0.944 & 0.971 \\
\hline Water consumption, L/d & 2.2 & 5.4 & 0.7 & 0.002 & 0.238 & 0.960 \\
\hline Respiration rate, breaths/min & 28 & 105 & 5 & 0.001 & 0.322 & 0.428 \\
\hline Rectal temperature, ${ }^{\circ} \mathrm{C}$ & 38.6 & 39.0 & 0.1 & 0.001 & 0.276 & 0.134 \\
\hline Rumen temperature, ${ }^{\circ} \mathrm{C}$ & 39.6 & 39.9 & 0.1 & 0.004 & 0.445 & 0.721 \\
\hline Rumen $\mathrm{pH}$ & 6.55 & 6.43 & 0.04 & 0.003 & 0.001 & 0.450 \\
\hline Urine $\mathrm{pH}$ & 7.79 & 7.77 & 0.09 & 0.834 & 0.335 & 0.265 \\
\hline
\end{tabular}


units at $3 \mathrm{~h}$ postfeeding, reaching the rumen $\mathrm{pH}$ nadir at a similar time. Despite eating the same diet and a similar DMI, mean daily rumen $\mathrm{pH}$ of the HS goats was 0.12 units lower than that of TN goats (Table 3; $P<$ 0.01). At most postfeeding time points, rumen $\mathrm{pH}$ of HS goats was lower than TN goats, although the difference was only significant for the interval 12 to $18 \mathrm{~h}$ after feeding (on average, $-0.21 \pm 0.05$ units; $P<0.001$ ). This time interval occurred during the night (shaded area in Figure 3) when the goats had finished their diet and were expected to be resting and ruminating. We hypothesized that HS goats had shorter rumination time as a consequence of panting, which produced a lower saliva secretion and impaired rumen buffering capacity, resulting in a lower rumen $\mathrm{pH}$. Similar to our results, Mishra et al. (1970) and Bandaranayaka and Holmes (1976) reported that rumen pH in HS cows was lower than in TN cows fed a similar amount of DM.

Logistic models of rumen $\mathrm{pH}$ values for $\mathrm{TN}$ and $\mathrm{HS}$ diets are shown in Figure 4a. The inflection points on the sigmoidal curves $(\mathrm{y}=720 \mathrm{~min} / \mathrm{d})$ for both $\mathrm{TN}(\mathrm{pH}$ $=6.53)$ and $\mathrm{HS}(\mathrm{pH}=6.40)$ were different according to conditions and close to the average $\mathrm{pH}$ values reported in Table 3, the AUC from $\mathrm{pH} 5.5$ to 7.0 being lower for TN than HS does $(675 \pm 128$ vs. $862 \pm 165 \mathrm{~min} / \mathrm{d}$ and pH unit, respectively; $P=0.046)$.

Rumen temperature evolution pattern was the opposite of that observed for rumen $\mathrm{pH}$ (Figure 3), in- creasing after feeding and slowly decreasing during the nocturnal period. The HS goats showed greater rumen temperature $\left(0.3 \pm 0.1^{\circ} \mathrm{C} ; P=0.004\right)$ than $\mathrm{TN}$ goats before feeding (Table 3) in accordance with the high ambient temperature under which the HS does were kept. Rectal temperature values were also greater (by $\left.0.4 \pm 0.1^{\circ} \mathrm{C} ; P=0.001\right)$ in the HS does, agreeing with the previously indicated rumen and ambient temperatures effects. As far as we know, rumen temperature has not been evaluated in farm animals under TN and HS conditions. Compared with values before feeding, TN and HS rumen temperatures increased at $1.5 \mathrm{~h}$ postfeeding $\left(0.23^{\circ} \mathrm{C} ; P<0.01\right)$ and peaked at $8 \mathrm{~h}$ postfeeding $\left(0.52^{\circ} \mathrm{C} ; P<0.001\right)$, gradually decreasing thereafter with the difference not being significant $(P=0.467)$ after $16.5 \mathrm{~h}$ postfeeding. There was no interaction treatment $\times$ hour $(P=0.721)$ for rumen temperature.

Rumen temperature values were also modeled using the logistic regression (Figure $4 \mathrm{~b}$ ), showing inflection points $(\mathrm{y}=720 \mathrm{~min} / \mathrm{d})$ at 39.62 and $39.89^{\circ} \mathrm{C}$ for the TN and HS conditions, which were close to the average temperature values reported in Table 3. Moreover the AUC from 35 to $41^{\circ} \mathrm{C}$ also differed according to the environmental conditions $(\mathrm{TN}=1,994 \pm 276 \mathrm{~min} / \mathrm{d}$ and ${ }^{\circ} \mathrm{C} ; \mathrm{HS}=1,599 \pm 198 \mathrm{~min} / \mathrm{d}$ and $\left.{ }^{\circ} \mathrm{C} ; P=0.008\right)$.

Rumen temperature and $\mathrm{pH}$ correlated in the whole goat data $(\mathrm{y}=-0.457 \mathrm{x}+24.63 ; \mathrm{r}=-0.73$; root mean square error $=0.19 ; P<0.01)$, but not enough re-

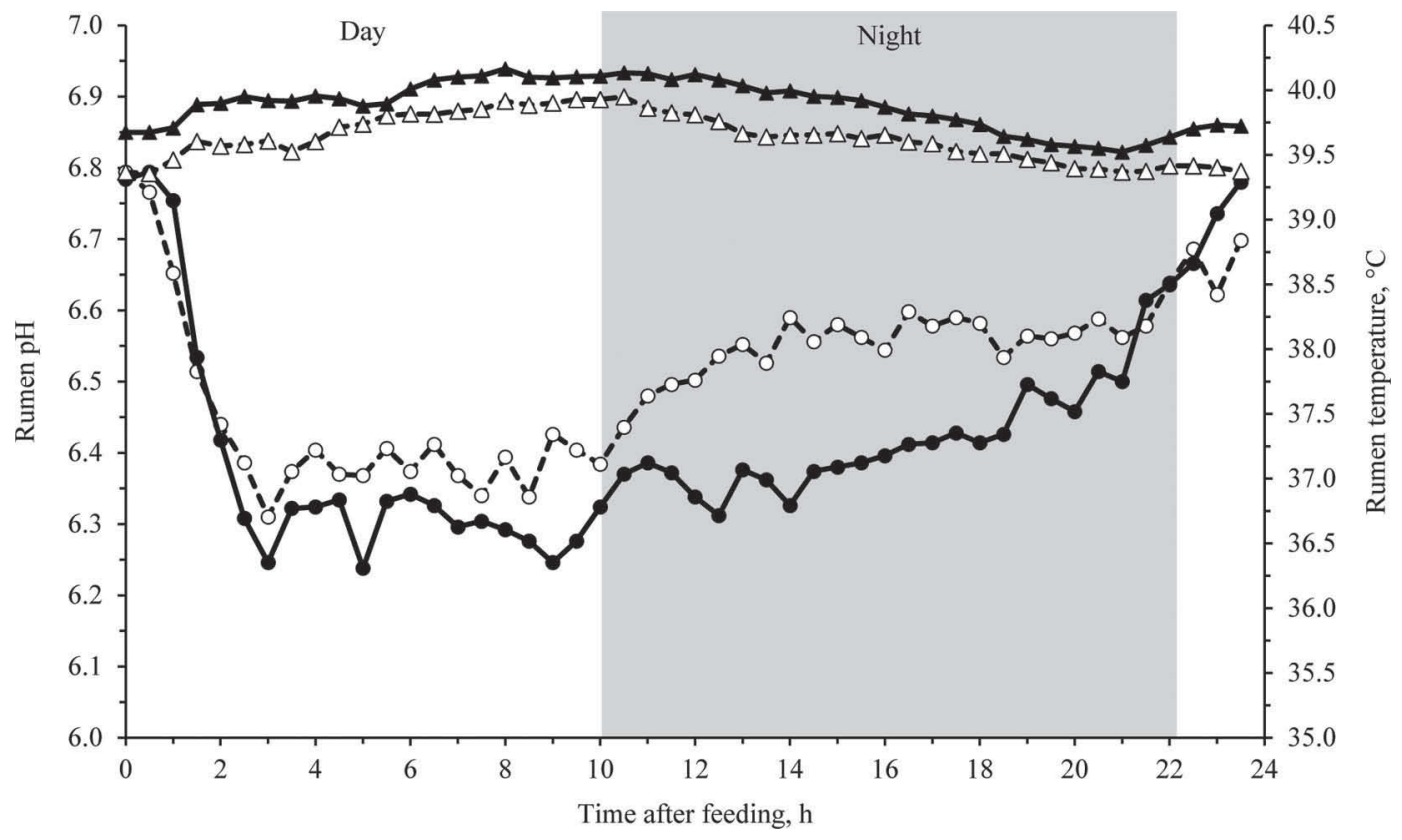

Figure 3. Ruminal pH $(\bigcirc$ and $\bullet$ ) and ruminal temperature $(\Delta$ and $\boldsymbol{\Delta})$ of goats of experiment 2 under thermal neutral $(\bigcirc, \Delta ; \mathrm{n}=8)$ or heat stress $(\boldsymbol{\bullet}, \mathbf{\Delta} ; \mathrm{n}=8)$ conditions. The shaded area indicates artificial night time (2100 to $0900 \mathrm{~h})$ during which ambient temperature was reduced from 37 to $30^{\circ} \mathrm{C}$ for heat-stressed goats. Outside this time interval, heat-stressed goats were exposed to $37^{\circ} \mathrm{C}$. The SEM values were 0.05 and 0.14 for rumen $\mathrm{pH}$ and temperature, respectively. 
a)

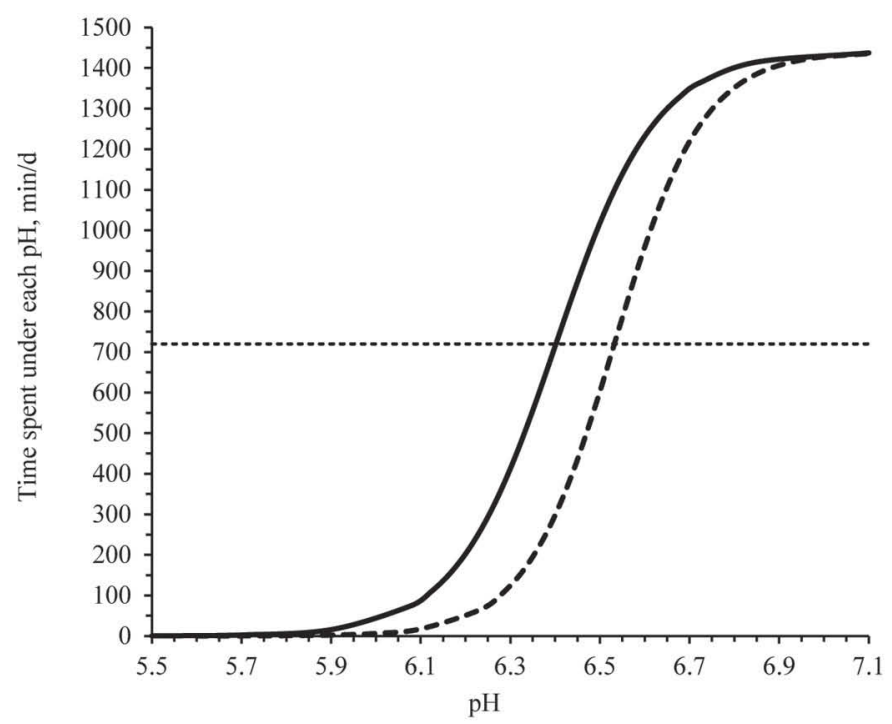

b)

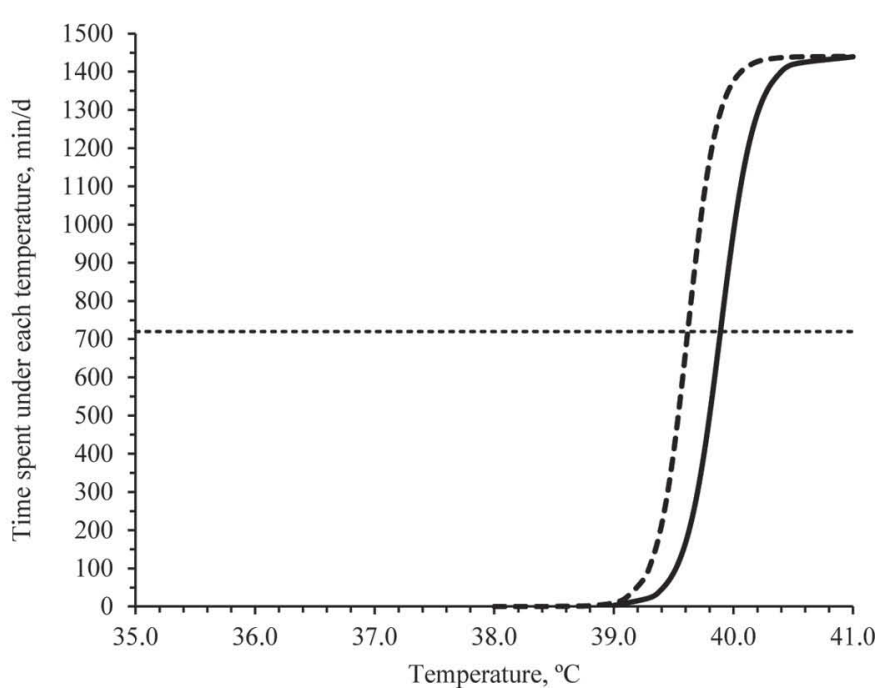

Figure 4. Logistic regression models for (a) the average rumen $\mathrm{pH}$ of goats of experiment 2 under thermoneutral $\left(---; y=\frac{1440}{1+e^{66.457-10.174 x}}\right.$; $\left.\mathrm{R}^{2}=0.974\right)$ or heat stress $\left(-; y=\frac{1440}{1+e^{57.450-8.974 x}} ; \mathrm{R}^{2}=0.987\right)$ conditions; and (b) the average rumen temperature of goats under thermoneutral $\left(---; y=\frac{1440}{1+e^{316.405-7.987 x}} ; \mathrm{R}^{2}=0.952\right)$ or heat stress $\left(-; y=\frac{1440}{1+e^{277.830-6.965 x}} ; \mathrm{R}^{2}=0.963\right)$ conditions and fed a diet with 50:50 forage-to-concentrate ratio at maintenance level. All regressions were $P<0.001$. The $y$-axis represents the accumulated time $(\mathrm{min} / \mathrm{d})$ spent below each corresponding $\mathrm{pH}$ or temperature $\left({ }^{\circ} \mathrm{C}\right)$ point on the $x$-axis.

lated to be used for prediction purposes. Rumen and rectal temperatures also showed a positive relationship $\left(\mathrm{R}^{2}=0.62 ; P<0.01\right)$, the rumen temperature being greater than the rectal temperature $\left(0.95 \pm 0.11^{\circ} \mathrm{C}\right.$, on average) in our dry and open goats, greater than the value obtained in experiment 1 under different feeding conditions.

Water Intake. As water was freely available at ambient temperature (i.e., 20 to $23^{\circ} \mathrm{C}$ for $\mathrm{TN}, 30$ to $37^{\circ} \mathrm{C}$ for HS), no marked decrease in rumen temperature was observed after drinking (Figure 3) such as those which occurred in experiment 1 when goats drank cold water once daily. Effects of HS in the rumen temperature of our goats were not mitigated by drinking cold water, as reported by Bewley et al. (2008) in dairy cows. Although we did not observe drops in the rumen temperature of the goats during the whole day, small drops hardly detectable were observed in rumen temperatures at 3 and $4 \mathrm{~h}$ after feeding (Figure 3 ) in the TN and HS goats, most likely as a result of drinking water at ambient temperature.

Digestibility Coefficients. Digestibility coefficients did not vary between TN and HS goats (Table 4). Previous results observed by Hamzaoui et al. (2013a,b) in lactating goats of the same breed fed ad libitum, showed improvements ( 3 to 9 points) in the digestibility coefficients of DM, CP, NDF, and ADF by the effect of HS. Moreover, HS increased the diet digestibility in male goats (Hirayama et al., 2004), dairy cows (McDowell et al., 1969), and dairy heifers (Bernabucci et al., 1999). In all mentioned studies, DMI decreased by HS, which might explain the increment of digestibility as a consequence of the depressed passage rate of the solid phase of digesta throughout the gastrointestinal tract, as reported by Silanikove et al. (1993) and Bernabucci et al. (1999). In the current study, DMI was similar between groups and, consequently, differences in digestibilities were minimal.

Blood Measures. Although HS goats lost BW, they were able to maintain a similar blood glucose and urea concentrations to TN goats (Table 5) in the short term, which agreed with their similar intake (Table 3 ) and nutrient digestibilities (Table 4) observed under our feeding conditions and agrees with Hamzaoui et al. (2013a) and Sano et al. (1985) in dairy goats and dairy ewes, respectively. Moreover, HS goats have been shown to have a pancreas less responsive in insulin secretion to a glucose tolerance test than TN goats as well as having kidneys that are able to produce glucose (Salama et al., 2014), these mechanisms allowing them to maintain the values of blood glucose during HS.

Blood $\mathrm{pH}$ was similar between TN and HS goats (Table 5), despite the increase in respiration rate reported in Table 3. An accelerated respiration rate (panting) is an important thermoregulatory response to HS and a key way for heat dissipation through evaporative cooling (Blackshaw and Blackshaw, 1994; Silanikove, 1994; 
Table 4. Digestibility coefficients of nonlactating goats of experiment 2 under thermal neutral $(\mathrm{TN}, \mathrm{n}=8)$ or heat stress (HS, $\mathrm{n}=8$ ) conditions; values are LSM

\begin{tabular}{|c|c|c|c|c|c|c|}
\hline \multirow[b]{2}{*}{ Item } & \multicolumn{2}{|c|}{ Treatment } & \multirow[b]{2}{*}{$\mathrm{SED}^{1}$} & \multicolumn{3}{|c|}{ Effect ( $P$-value) } \\
\hline & $\mathrm{TN}$ & HS & & Treatment & Period & Sequence $^{2}$ \\
\hline DM & 75.8 & 77.7 & 2.2 & 0.421 & 0.326 & 0.373 \\
\hline $\mathrm{OM}$ & 78.3 & 79.8 & 2.1 & 0.513 & 0.359 & 0.425 \\
\hline $\mathrm{CP}$ & 77.4 & 79.1 & 2.0 & 0.423 & 0.183 & 0.178 \\
\hline NDF & 51.1 & 56.6 & 4.2 & 0.230 & 0.279 & 0.737 \\
\hline $\mathrm{ADF}$ & 50.1 & 52.6 & 4.8 & 0.211 & 0.164 & 0.875 \\
\hline
\end{tabular}

Beatty et al., 2006). Panting eliminates pulmonary $\mathrm{CO}_{2}$ faster than it is produced and, consequently, reduces blood $\mathrm{CO}_{2}$ pressure, which tends to raise blood $\mathrm{pH}$ and decrease the concentration of $\mathrm{HCO}_{3}{ }^{-}$and its buffer role. To restore the $\mathrm{pH}$ to normal, panting must be stopped or the kidneys must eliminate $\mathrm{HCO}_{3}^{-}$. The latter occurs because the low blood $\mathrm{CO}_{2}$ pressure and alkalosis reduce $\mathrm{H}^{+}$and $\mathrm{NH}_{3}$ production by the kidneys (Calamari et al., 2007).

In our data, increased alveolar ventilation contributed to a greater pulmonary loss of $\mathrm{CO}_{2}$ and to a decrease in blood $\mathrm{CO}_{2}$ pressure and total $\mathrm{CO}_{2}$ of $\mathrm{HS}$ goats $(P$ $<0.01$; Table 5), decreasing $\mathrm{HCO}_{3}{ }^{-}$and base excess in the blood of HS goats to maintain constant blood $\mathrm{pH}(P<0.01$; Table 5$)$. No effects were detected on urea in plasma $(P=0.570)$. The reduction in blood $\mathrm{HCO}_{3}{ }^{-}$concentration under HS leads to a decrease in the buffering capacity of the saliva arriving to the rumen (Guilloteau et al., 1995) and, consequently, lower rumen $\mathrm{pH}$, as observed in our HS goats.

Hematocrit and hemoglobin values were lower $(P=$ 0.034) in HS than TN goats (Table 5). Weldy et al. (1964) reported a negative correlation $(\mathrm{r}=-0.44)$ between blood cell volume and rectal temperature under HS conditions in dairy cows. It seems that increased water consumption by HS does (Table 3) caused an hemodilution effect by increasing the plasma volume, the extra water amount being incorporated into the circulatory system for evaporative cooling (Silanikove, 1992).

\section{CONCLUSIONS}

Ruminal $\mathrm{pH}$ and temperature sensors were able to record a large amount of data $(>10,000)$ that was useful to detect diurnal fluctuations of ruminal $\mathrm{pH}$ and temperature in relation to management and environmental changes. Continuous recording allowed modeling and measuring the amount of time spent below a critical $\mathrm{pH}$ or temperature points, which could add further soundness to the interpretation of data. By means of these sensors, we were able to detect a lower rumen $\mathrm{pH}$ in HS goats, even when they had similar feed intake to goats under TN conditions. Effects of water temperature and changes in rumen fermentation and absorption of metabolites across the rumen wall under same nutrition and HS conditions need further research.

\section{ACKNOWLEDGMENTS}

This work is part of a research project (Plan Nacional I+D+I, Project AGL-2013-44061R) funded by the Spanish Ministry of Economy and Finances (Madrid, Spain). The authors are also grateful to Ramon Costa and the team of the Servei de Granges i Camps Experimentals of the Universitat Autònoma de Barcelona (Bellaterra, Barcelona, Spain) for the care of the animals, to Kahne Ltd. (Auckland, New Zealand) for the technical support, and to Nic Aldam (Barcelona, Spain) for the English revision of the manuscript.

Table 5. Metabolic and acid-base balance indicators of nonlactating goats of experiment 2 under thermal neutral $(\mathrm{TN}, \mathrm{n}=4)$ or heat stress $(\mathrm{HS}, \mathrm{n}=4)$ conditions; values are least squares means

\begin{tabular}{|c|c|c|c|c|}
\hline \multirow[b]{2}{*}{ Item } & \multicolumn{2}{|c|}{ Treatment } & \multirow[b]{2}{*}{$\mathrm{SED}^{1}$} & \multirow{2}{*}{$\begin{array}{c}\text { Effect } \\
(P \text {-value }\end{array}$} \\
\hline & $\mathrm{TN}$ & HS & & \\
\hline Glucose, mg/dL & 57.7 & 55.0 & 5.2 & 0.630 \\
\hline Urea, mg/dL & 14.3 & 13.3 & 1.8 & 0.571 \\
\hline $\mathrm{Na}, \mathrm{mmol} / \mathrm{L}$ & 149 & 152 & 1 & 0.021 \\
\hline $\mathrm{K}, \mathrm{mmol} / \mathrm{L}$ & 3.47 & 3.83 & 0.30 & 0.292 \\
\hline $\mathrm{Cl}, \mathrm{mmol} / \mathrm{L}$ & 111 & 119 & 2 & 0.017 \\
\hline Hematocrit, \% $\mathrm{PCV}^{2}$ & 18.3 & 15.3 & 1.0 & 0.032 \\
\hline Hemoglobin, ${ }^{3} \mathrm{mmol} / \mathrm{L}$ & 6.23 & 5.18 & 0.37 & 0.034 \\
\hline $\mathrm{pH}$ & 7.45 & 7.47 & 0.02 & 0.510 \\
\hline Total $\mathrm{CO}_{2},{ }^{3} \mathrm{mmol} / \mathrm{L}$ & 30 & 22 & 2 & 0.009 \\
\hline Anion gap, ${ }^{3} \mathrm{mmol} / \mathrm{L}$ & 12.7 & 15.5 & 1.1 & 0.044 \\
\hline $\mathrm{CO}_{2}$ pressure, $\mathrm{mmHg}$ & 42 & 29 & 3 & 0.006 \\
\hline $\mathrm{HCO}_{3},{ }^{3} \mathrm{mmol} / \mathrm{L}$ & 28.8 & 21.1 & 1.8 & 0.007 \\
\hline Base excess ${ }^{3}$ & 4.67 & -2.75 & 1.97 & 0.010 \\
\hline
\end{tabular}

${ }^{1} \mathrm{SED}=$ standard error of the difference.

${ }^{2} \mathrm{PCV}=$ packed cell volume.

${ }^{3}$ Calculated by the VetScan i-STAT 1 device software (Abaxis, Union City, CA). 


\section{REFERENCES}

AlZahal, O., H. AlZahal, M. A. Steele, M. Van Schaik, I. Kyriazakis, T. F. Duffield, and B. W. McBride. 2011. The use of a radiotelemetric ruminal bolus to detect body temperature changes in lactating dairy cattle. J. Dairy Sci. 94:3568-3574.

AlZahal, O., E. Kebreab, J. France, M. Froetschel, and B. W. McBride. 2008. Ruminal temperature may aid in the detection of subacute ruminal acidosis. J. Dairy Sci. 91:202-207.

AlZahal, O., E. Kebreab, J. France, and B. W. McBride. 2007. Mathematical approach to predicting biological values from ruminal $\mathrm{pH}$ measurements. J. Dairy Sci. 90:3777-3785.

AlZahal, O., M. A. Steele, E. V. Valdes, and B. W. McBride. 2009. Technical note: The use of a telemetric system to continuously monitor ruminal temperature and to predict ruminal $\mathrm{pH}$ in cattle. J. Dairy Sci. 92:5697-5701.

AOAC International. 2003. Official Methods of Analysis. Vol. I. 17th ed. AOAC International, Rockville, MD.

Arieli, A., Y. Aharoni, S. Zamwel, and H. Tagari. 1988. Effect of ratio of roughage concentrate on glucose-induced heat production in sheep rumen fluid in vitro. J. Dairy Sci. 71:964-970.

Bandaranayaka, D. D., and C. W. Holmes. 1976. Changes in the composition of milk and rumen contents in cows exposed to a high ambient temperature with controlled feeding. Trop. Anim. Health Prod. 8:38-46.

Baumgard, L. H., and R. P. Rhoads. 2013. Effects of heat stress on postabsorptive metabolism and energetics. Annu. Rev. Anim. Biosci. 1:311-337.

Beatty, D. T., A. Barnes, E. Taylor, D. Pethick, M. McCarthy, and S. K. Maloney. 2006. Physiological responses of Bos taurus and Bos indicus cattle to prolonged, continuous heat and humidity. J. Anim. Sci. 84:972-985.

Beede, D. K., and R. J. Collier. 1986. Potential nutritional strategies for intensively managed cattle during thermal stress. J. Anim. Sci. $62: 543-554$.

Bernabucci, U., P. Bani, B. Ronchi, N. Lacetera, and A. Nardone. 1999. Influence of short- and long-term exposure to a hot environment on rumen passage rate and diet digestibility by Friesian heifers. J. Dairy Sci. 82:967-973.

Bewley, J. M., M. W. Grott, M. E. Einstein, and M. M. Schutz. 2008. Impact of intake water temperatures on reticular temperatures of lactating dairy cows. J. Dairy Sci. 91:3880-3887.

Blackshaw, J. K., and A. W. Blackshaw. 1994. Heat stress in cattle and the effect of shade on production and behaviour: A review. Aust. J. Exp. Agric. 34:285-295.

Calamari, L., F. Abeni, F. Calegari, and L. Stefanini. 2007. Metabolic conditions of lactating Friesian dairy cows during the hot season in the Po valley. 2. Blood minerals and acid-base chemistry. Int. J. Biometeorol. 52:97-107.

Cantalapiedra-Hijar, G., D. R. Yáñez-Ruiz, A. I. Martín-García, and E. Molina-Alcaide. 2009. Effects of forage:concentrate ratio and forage type on apparent digestibility, ruminal fermentation, and microbial growth in goats. J. Anim. Sci. 87:622-631.

Cooper-Prado, M. J., N. M. Long, E. C. Wright, C. L. Goad, and R. P. Wettemann. 2011. Relationship of ruminal temperature with parturition and estrus of beef cows. J. Anim. Sci. 89:1020-1027.

Dehghani, S. N., and A. M. Ghadrdani. 1995. Bovine rumenotomy: Comparison of four surgical techniques. Can. Vet. J. 36:693-697.

Eigenberg, R. A., T. M. Brown-Brandl, and J. A. Nienaber. 2008. Sensors for dynamic physiological measurements. Comput. Electron. Agric. 62:41-47.

Enemark, J. M. D., G. Peters, and R. J. Jørgensen. 2003. Continuous monitoring of rumen $\mathrm{pH}$. A case study with cattle. J. Vet. Med. A Physiol. Pathol. Clin. Med. 50:62-66.

Giger-Reverdin, S., P. Morand Fehr, and D. Sauvant. 2011. Water intake of dairy goats in intensive systems. Options Médit. 99:233237.

Giger-Reverdin, S., K. Rigalma, M. Desnoyers, D. Sauvant, and C. Duvaux-Ponter. 2014. Effect of concentrate level on feeding behavior and rumen and blood parameters in dairy goats: Relation- ships between behavioral and physiological parameters and effect of between-animal variability. J. Dairy Sci. 97:4367-4378.

Guilloteau, P., I. Le Huërou-Luron, C. H. Malbert, and R. Toullec. 1995. Les secretions digestives et leur regulation. Pages 489-526 in Nutrition des Ruminats Domestiques. R. Jarrige, Y. Ruckebusch, C. Demarquilly, M. H. Farce, and M. Jounet, ed. INRA Editions, Paris, France.

Hamzaoui, S., A. A. K. Salama, E. Albanell, X. Such, and G. Caja. 2013a. Physiological responses and lactational performances of late lactating dairy goats under heat stress conditions. J. Dairy Sci. 96:6355-6365.

Hamzaoui, S., A. A. K. Salama, G. Caja, E. Albanell, C. Flores, and X. Such. 2012. Milk production losses in early lactating dairy goats under heat stress. J. Dairy Sci. 95(Suppl. 2):672-673.

Hamzaoui, S., A. A. K. Salama, G. Caja, E. Albanell, and X. Such. 2013b. Supplementation with soybean oil increases milk fat and improves milk fatty acid profile in heat-stressed dairy goats. J. Dairy Sci. 96(E-Suppl. 1):124.

Harris, D. C. 1998. Nonlinear least-squares curve fitting with Microsoft Excel Solver. J. Chem. Educ. 75:119-121.

Hassanat, F., R. Gervais, C. Julien, D. I. Massé, A. Lettat, P. Y. Chouinard, H. V. Petit, and C. Benchaar. 2013. Replacing alfalfa silage with corn silage in dairy cow diets: Effects on enteric methane production, ruminal fermentation, digestion, $\mathrm{N}$ balance, and milk production. J. Dairy Sci. 96:4553-4567.

Hirayama, T., K. Katoh, and Y. Obara. 2004. Effects of heat exposure on nutrient digestibility, rumen contraction and hormone secretion of goats. Anim. Sci. J. 75:237-243.

Hungate, R. E. 1966. The Rumen and its Microbes. Academic Press Inc., New York, NY.

INRA. 2007. Alimentation des Bovins, Ovins et Caprins. Quae, Paris, France.

Kahne. 2010. User Guide: KB1000 Kahne bolus series. Kahne Ltd, Auckland, New Zealand.

Kaur, R., S. C. Garcia, A. Horadagoda, and W. J. Fulkerson. 2010. Evaluation of rumen probe for continuous monitoring of rumen $\mathrm{pH}$, temperature and pressure. Anim. Prod. Sci. 50:98-104.

Kelley, R. O., F. A. Martz, and H. D. Johnson. 1967. Effect of environmental temperature on ruminal VFA levels with controlled feed intake. J. Dairy Sci. 50:531-533.

Lohölter, M., R. Rehage, U. Meyer, P. Lebzien, J. Rehage, and S. Dänicke. 2013. Evaluation of a device for continuous measurement of rumen $\mathrm{pH}$ and temperature considering localization of measurement and dietary concentrate proportion. Appl. Agric. Forestry Res. 63:61-68.

McDowell, R. E., E. G. Moody, P. J. Van Soest, R. P. Lehmann, and G. L. Ford. 1969. Effect of heat stress on energy and water utilization of lactating cows. J. Dairy Sci. 52:188-194.

Mishra, M., F. A. Martz, R. W. Stanley, H. D. Johnson, J. R. Campbell, and E. Hilderbrand. 1970. Effect of diet and ambient temperature-humidity on ruminal $\mathrm{pH}$, oxidation reduction potential, ammonia and lactic acid in lactating cows . J. Anim. Sci. 30:10231028.

Mullins, C. R., L. K. Mamedova, M. J. Brouk, C. E. Moore, H. B Green, K. L. Perfield, J. F. Smith, J. P. Harner, and B. J. Bradford. 2012. Effects of monensin on metabolic parameters, feeding behavior, and productivity of transition dairy cows. J. Dairy Sci. 95:1323-1336.

NRC. 1971. A Guide to Environmental Research on Animals. Natl. Acad. Press. Washington, DC.

Rose-Dye, T. K., L. O. Burciaga-Robles, C. R. Krehbiel, D. L. Step, R. W. Fulton, A. W. Confer, and C. J. Richards. 2011. Rumen temperature change monitored with remote rumen temperature boluses following challenges with Bovine Viral Diarrhea Virus and Mannheimia haemolytica. J. Anim. Sci. 89:1193-1200.

Rutten, C. J., A. G. J. Velthuis, W. Steeneveld, and H. Hogeveen. 2013. Invited review: Sensors to support health management on dairy farms. J. Dairy Sci. 96:1928-1952.

Salama, A. A. K., G. Caja, S. Hamzaoui, B. Badaoui, A. CastroCosta, D. A. E. Façanha, M. M. Guilhermino, and R. Bozzi. 2014. 
Different levels of response to heat stress in dairy goats. Small Rumin. Res. 121:73-79.

Sano, H., K. Ambo, and T. Tsuda. 1985. Blood glucose kinetics in whole body and mammary gland of lactating goats exposed to heat stress. J. Dairy Sci. 68:2557-2564.

Silanikove, N. 1992. Effects of water scarcity and hot environment on appetite and digestion in ruminants: A review. Livest. Prod. Sci. 30:175-194.

Silanikove, N. 1994. The struggle to maintain hydration and osmoregulation in animals experiencing severe dehydration and rapid rehydration: the story of ruminants. Exp. Physiol. 79:281-300.

Silanikove, N. 2000a. Effects of heat stress on the welfare of extensively managed domestic ruminants. Livest. Prod. Sci. 67:1-18.

Silanikove, N. 2000b. The physiological basis of adaptation in goats to harsh environments. Small Rumin. Res. 35:181-193.
Silanikove, N., H. Tagari, and A. Shkolnik. 1993. Comparison of rate of passage, fermentation rate and efficiency of digestion of high fiber diet in desert Bedouin goats compared to Swiss Saanen goats. Small Rumin. Res. 12:45-60.

Tajima, K., I. Nonaka, K. Higuchi, N. Takusari, M. Kurihara, A. Takenaka, M. Mitsumori, H. Kajikawa, and R. I. Aminov. 2007. Influence of high temperature and humidity on rumen bacterial diversity in Holstein heifers. Anaerobe 13:57-64.

Wahrmund, J. L., J. R. Ronchesel, C. R. Krehbiel, C. L. Goad, S. M. Trost, and C. J. Richard. 2012. Ruminal acidosis challenge impact on ruminal temperature in feedlot cattle. J. Anim. Sci. 90:2794-2801.

Weldy, J. R., R. E. McDowell, P. J. Van Soest, and J. Bond. 1964. Influence of heat stress on rumen acid levels and some blood constituents in cattle. J. Anim. Sci. 23:147-153. 